\title{
THE EFFECT OF CORPORATE SOCIAL RESPONSIBILITY DISCLOSURE ON PROFITABILITY AND COMPANY VALUE
}

\begin{tabular}{|c|c|}
\hline $\begin{array}{l}\text { Aurora Ang } \\
{ }_{123} \text { Univ }\end{array}$ & $\begin{array}{l}\text { inny Stephanie Hidayat }{ }^{2} \text { Oktavianti }{ }^{3} \\
\text { Kristen Maranatha, Bandung Indonesia } \\
\text { aurora.ang3l@gmail.com }\end{array}$ \\
\hline INFO ARTIKEL & ABSTRACT \\
\hline $\begin{array}{l}\text { Histori Artikel : } \\
\text { Tgl. Masuk : } 13-01-2021 \\
\text { Tgl. Diterima : 02-03-2021 } \\
\text { Tersedia Online : 31-03-2021 } \\
\text { Keywords: } \\
\text { CSR disclosure, profitability, company } \\
\text { value }\end{array}$ & $\begin{array}{l}\text { This study aims at determining the effect of CSR disclosure } \\
\text { on profitability and company value. This study uses the } \\
\text { population of all companies included in the LQ45 group } \\
\text { listed on the IDX for three consecutive years, namely } 2017 \text {, } \\
2018 \text {, and 2019. The technique to test the hypothesis is } \\
\text { Simple Linear Regression Analysis. It is used to determine } \\
\text { the effect of CSR disclosure on profitability and the effect of } \\
\text { CSR disclosure on company value. The result of this study } \\
\text { is the disclosure of CSR does not have a significant effect } \\
\text { on profitability neither does it affect the company value. } \\
\text { Despite the fact that the results show that CSR disclosure } \\
\text { does not have a significant effect, the authors suggest that } \\
\text { companies continue carrying out CSR activities because it } \\
\text { is a long-term investment activity. }\end{array}$ \\
\hline
\end{tabular}

\section{INTRODUCTION}

The awareness of the business people to apply Corporate Social Responsibility (CSR) in Indonesia has been relatively new since it was just initiated in 1990. It is due to the assumption among the business people that social responsibility is merely a waste. This is to be pitied on because the CSR program, as a matter of fact, gives a lot of advantages to the company. There has been a constant new spectrum in the world of business in Indonesia concerning the importance of business to raise its awareness of the corporate social responsibility (Rochayatun, 2016).

One of the advantages of a constant application of CSR is a much stronger profitability and financial performance. The revelation of CSR, in the form of a report, functions as the investors' consideration when involved in the activity of investment and the identification of the success of a company within a certain period of time
(Putra, 2015). Current business practitioners in Indonesia are aware of the importance of CSR, and thus makes use of it as one of the strategies to boost the company image, which will have an effect on its financial performance and company value. One example is that there were 100 companies that won the Indonesia Top Corporate Social Responsibility of the year 2020. To determine the company that won the award, a survey was conducted in March - May 2020, of more than 500 companies surveyed in Indonesia. The 100 winners of Top Corporate Social Responsibility of the year 2020 consist of BUMN / BUMD companies (20\%) and private companies (80\%). Business practitioners realize doing CSR can build a positive image of the company in the public (https://www.bengkulunews.co.id.2020/06 /09). Companies that have a positive image in the public will certainly attract consumers and investors. So that there is 
a relationship that CSR is a company strategy to increase profitability and company value. In this research the writer utilizes the financial performance and company value as dependent variables. They are to be measured by the profitability ratios (ROA) and Tobin's $Q$ respectively. The CSR disclosure is conducted with the hope of giving positive impacts to the profitability and company value.

\section{LITERATURE REVIEW AND HYPOTHESIS DEVELOPMENT}

\section{Corporate Social Responsibility}

CSR is a concept which states that a company basically accounts for its consumers, workers, shareholders, community and environment in all aspects of the company operation. CSR application will have an effect on the continuity of the company. The activities of a company must base its decisions on not only the profit and dividends but also the social consequence at the present time and in the long run (Untung, 2012).

Fahmi (2014) asserts that CSR is the commitment of a company or the world of business to contribute to the development of the economy consistently by paying attention to the social responsibility of the company and constantly focusing on the aspects of economy, social and environment.

\section{The principles of Corporate Social Responsibility}

Hadi (2011) in his book specifies the principles of social responsibilities, according to Crowther David (2008), into three elements. They are:

1. Sustainability

It is concerned with the way the company runs its activities while taking into accounts the continuity of the resource in the future. Sustainability revolves around the alignments and efforts of the society to make use of the resource to be sustainable for the future generations.

\section{Accountability}

It is the company's effort and responsibility to the activities having been carried out. Accountability is essential when the company's activities affect and are affected by the external environment. The particular concept explains the quantitative effects of the company activities to the internal and external parties.

3. Transparency

It is an important principle for the external party. Transparency intersects with the report of the company activities along with its impact to the external party. It is of the utmost importance for the party since it reduces the asymmetrical information and misunderstandings, particularly in terms of information and responsibility towards the various impacts on environments.

\section{The benefits of Corporate Social Responsibility}

The benefits of corporate social responsibility according to ISO 26000 are:

- To encourage further information in decision making that goes along with an increasing understanding of people's expectations.

- To improve the risk management practices of the organization.

- To improve the reputation of the organization and foster a greater public trust.

- To improve the organizational competitiveness.

- To improve the organization's relationship with stakeholders and its capacity for innovation with constant exposure to new perspectives and contact with stakeholders.

- To increase the employee's loyalty and morale, improve the safety and health of both male and female workers, which will have a positive impact on the organization's ability to recruit, motivate and retain employees.

- To obtain savings associated with the increasing productivity and resource efficiency, lower water and energy 
consumption, reduced waste, and increasing availability of raw materials.

- To increase the reliability and fairness of transactions through an accountable political engagement, fair competition and the absence of corruption.

- To prevent or reduce potential conflicts with consumers as far as products or services are concerned.

- To contribute to the long-term sustainability of the organization by promoting the sustainability of natural resources and environmental services.

- To contribute to the society and strengthen the general public and institutions.

\section{Profitability}

Profitability has something to do with the efficient use of the company's assets and other resources in its operations. According to Hery (2017), the profitability ratio is the ability of a company to generate a profit or profits within a certain period of time. Profitability calculations are specified into three groups (Riyanto, 2012). They are:

1. Profit Margin (Net Profit Margin). This ratio is a comparison between the net income and sales.

2. Asset Return Ratio (ROA), which is the ratio between the net income and total assets.

3. Return on Equity Ratio (ROE). This ratio is a comparison between the net income and equity.

The objectives of the profitability ratio, according to Hery (2017), are as follows:

- To measure the company's ability to generate profits during a certain period of time.

- To assess the company's profit position from the previous year to the current one.

- To assess the progress of profit over time.

- To measure the amount of the net profit to be generated from each rupiah of funds invested in the asset capital.

- To measure the amount of net profit to be generated from each rupiah of funds invested in equity capital.
- To measure the gross profit margin on the net sales.

- To measure the operating profit margin on the net sales.

- To measure the net profit margin on the net sales.

\section{Company value}

The ratio utilized to measure company value is Tobin's $Q$. This ratio is considered to give the best information since Tobin's $Q$ incorporates all elements of debt and share capital of the company. It includes not only ordinary shares but company equity and assets as well. The inclusion means that the company focuses on not only investors but also creditors. It is because the source of the company's operational financing roots is from its equity and loans from the creditors (Dewi, 2017).

Tobin's $Q$ is hereby formulated into:

$$
Q=\frac{E M V+D}{E B V+D}
$$

EMV (Equity Market Value) is the market value of equity earned from multiplying the closing stock price with the number of outstanding shares at the end of the year. EBV (Equity Book Value) is the book value of equity gained from the difference between the company's total assets and total liabilities.

$\mathrm{D}$ (debt) is the book value of the total debt.

\section{CSR Disclosure has an effect on Profitability}

Based on Heryanto and Juliarto's research (2017) entitled The Influence of Corporate Social Responsibility on Company Profitability. The result shows that CSR has a positive effect on profitability as measured by Return on Assets (ROA), Return on Equity (ROE), Earning per Share (EPS), and Net Profit Margin (NPM). The CSR variable in this research shows how much the disclosure of the company's activities in carrying out its obligations to the social environment. From this study it is concluded that the more companies that disclose their CSR in their annual reports, companies profitability will increase.

Another research by Husnan and Pamudji (2013) concluded that CSR has a 
significant effect on profitability as proxied by Return on Assets (ROA) and Return on Sales (ROS). This is because CSR disclosure in the form of social activities by companies can give trust to external parties such as the wider community. Putra (2015) also make research entitled The Effect of Corporate Social Responsibility on Company Profitability. The results show that there is a positive and significant effect of CSR on company profitability as measured by Return on Assets (ROA), there is a positive but not significant effect of CSR on company profitability as measured by Return on Equity (ROE), there is a positive and significant effect of CSR on Company profitability as measured by Net Profit Margin (NPM).

Companies that doing CSR continously will enhance the company's image in the eyes of consumers and society. This corporate image enhancement is expected to increase the company's profitability. The hypothesis can be formulated:

$\mathrm{H} 1$ : CSR disclosure has an effect on profitability.

\section{CSR Disclosure has an effect on the Company Value}

Based on research by Fasya (2018) entitled The Effect of Disclosure of Corporate Social Responsibility on Company Value with Profitability as a Moderation Variable. The results showed that CSR has a positive effect on company value, ROA has a positive effect on company value, ROA strengthens the positive influence between CSR on company value.

Another research by Dewi and Biyantari (2017) concluded that CSR has an effect on company value. CSR can have a positive impact on the company, where by doing CSR activities the company can increase public trust in the company's products, so that the company's reputation also increases in the eyes of the community. A good company image will increase company value. The hypothesis can be formulated:

$\mathrm{H} 2$ : CSR disclosure has an effect on company value.

\section{RESEARCH METHODS}

This study attempts to identify the effect of CSR disclosure on the profitability and company value. Thus, the analysis belongs to a descriptive analysis. The possibility of quantifying a number of data is still viable, such as using statistical tables, data analysis and conclusions. However, the study will rely more on qualitative interpretation with descriptive statistical data as the main vehicle in data processing.

The population of this study are all companies included in the LQ45 group listed on the IDX in 2017, 2018, and 2019. The sample used in this study is selected using the purposive sampling method to obtain a representative sample according to the specified criteria as follows:

- IPO dated prior to 2017

- Registered on LQ 45 for the period of 2017, 2018, 2019

- Every company must publish a sustainability report and an annual report in a row in the year of 2017,2018 , 2019

This study makes use of secondary data, namely published data. The secondary data in question is the annual report and sustainability report of companies included in the LQ45 group listed on the IDX for three consecutive years: 2017, 2018, and 2019. The other secondary data is obtained using literature study methods and relevant literature review from both textbooks and scientific journals.

This study consists of independent variables namely CSR and dependent ones namely profitability and company value. To be more specific, the operationalization of this research variable is as follows:

- Variable X $\rightarrow$ CSR

The CSR disclosure in the company's annual report stated in the Corporate Social Responsibility Index (CSRI) is assessed by comparing the number of disclosures made by the company with the required number by GRI-G4, including 94 disclosure items which covers all aspects of sustainability, namely economic, 
environmental and social as well as contributing indicators. Each of the CSR items in the research instrument is given a score of 1 if there is a disclosure and a score of 0 if there is none. Subsequently, the scores are totally calculated to obtain the overall score for each company as follows:

CSRIj $=\frac{\Sigma X i j}{n j}$

- Variable Y1 $\rightarrow$ Profitability

Measuring profitability using the ROA formula is as follows:

$\mathrm{ROA}=\underline{\text { Net income }}$

Total Assets

- Variable Y2 $\rightarrow$ Company value

Measuring company value using Tobin's $Q$ ratio is formulated as follows:

$\mathrm{Q}=\frac{\mathrm{EMV}+\mathrm{D}}{\mathrm{EBV}+\mathrm{D}}$

\section{RESULTS AND DISCUSSION}

\section{Data Analysis and Hypothesis Testing}

Based on the specified sample criteria, there are 22 companies meeting the criteria using the three-year observation method $(2017,2018,2019)$. To provide an overview of the data, descriptive statistics are conducted. This includes the minimum, maximum, mean, and standard deviation values of all the studied variables.

\begin{tabular}{|c|c|c|c|c|c|}
\hline & $\mathrm{N}$ & $\begin{array}{l}\text { Minimu } \\
\mathrm{m}\end{array}$ & $\begin{array}{l}\text { Maximu } \\
\mathrm{m}\end{array}$ & $\begin{array}{l}\text { Mea } \\
n\end{array}$ & $\begin{array}{l}\text { Std. } \\
\text { Deviati } \\
\text { on }\end{array}$ \\
\hline CSR & 66 & .02 & .63 & .213 & 10157. \\
\hline ROA & 66 & -.70 & 46.30 & 6.76 & 8.6968 \\
\hline $\mathrm{Q}$ & 66 & .83 & 23.29 & $\begin{array}{l}2.24 \\
9 ?\end{array}$ & 3.8346 \\
\hline $\begin{array}{l}\text { Valid N } \\
\text { (listwis } \\
\text { e) }\end{array}$ & 66 & & & & \\
\hline
\end{tabular}

The data in this study have been tested and met the classical assumption test comprising normality test, autocorrelation test, multicollinearity test, and heteroscedasticity test.
In the particular study, there are two regression equations applied. The first equation is used to analyze the effect of CSR on ROA. The second is to analyze the effect of CSR on the value of the company. The equation model in the study is as follows:

1. $Y 1=a+b 1 X$

2. $Y 2=a+b 1 X$

The following is the table of the results of simple linear regression analysis processed with the SPSS program:

\begin{tabular}{|c|c|c|c|c|c|}
\hline \multirow[t]{2}{*}{ Model } & \multicolumn{2}{|c|}{$\begin{array}{l}\text { Unstandardize } \\
\text { d Coefficients }\end{array}$} & \multirow{2}{*}{$\begin{array}{l}\text { Standa } \\
\text { rdized } \\
\text { Coeffici } \\
\text { ents } \\
\text { Beta }\end{array}$} & \multirow[t]{2}{*}{$t$} & \multirow[t]{2}{*}{ Sig. } \\
\hline & $B$ & \begin{tabular}{|l} 
Std. \\
Error
\end{tabular} & & & \\
\hline $\begin{array}{ll} & \text { (Con } \\
1 & \text { stant) }\end{array}$ & 8.355 & 2.513 & & $\begin{array}{l}3.32 \\
5\end{array}$ & .001 \\
\hline CSR & 7.485 & 10.662 & .087 & .702 & .485 \\
\hline
\end{tabular}

a. Dependent Variable: ROA

The results of calculating the regression coefficient based on the obtained research data is written in the regression equation as follows:

The first equation: $\mathrm{Y} 1=8,355+7,485 \mathrm{X}$

The first equation has a significant level of 0.485 . This is greater than 0.05 . Thus, it can be concluded that CSR disclosure has no significant effect on ROA.

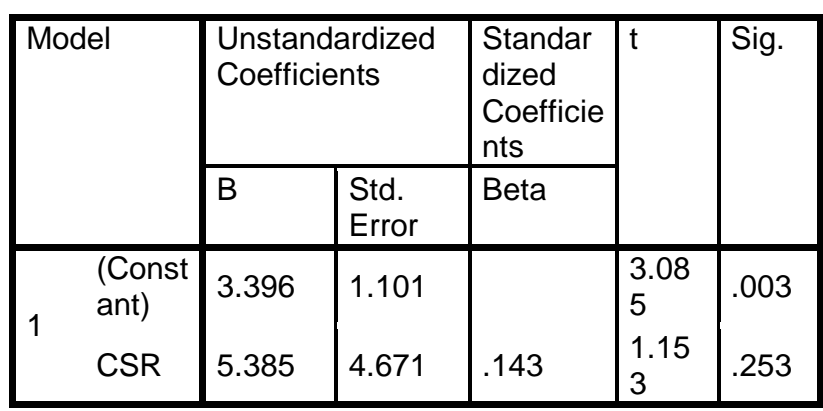

a. Dependent Variable: TobinsQ

The second equation: $\mathrm{Y} 2=3,396+5,385 \mathrm{X}$ The second equation has a significant level of 0.253 which is greater than 0.05 . Thus, it can be explained that CSR disclosure has no significant effect on the company value (Tobin's $Q$ ). 


\section{The Effect of the CSR Disclosure on Profitability}

The first hypothesis of the study is that CSR disclosure has an effect on profitability $(\mathrm{ROA})$. From the results of statistical data processed through the significance test, it is obtained 0.485 which is greater than the $5 \%$ error level $(\alpha=$ 0.05). This means that $\mathrm{H} 1$, which states that CSR disclosure has an effect on profitability $(\mathrm{ROA})$, is rejected. Thus, it can be concluded that CSR disclosure has no significant effect on ROA.

This research is in line with research conducted by Parengkuan (2017), Fatah and Haryanto (2016), and Ekasari (2012), all of which state that CSR does not have a significant effect on ROA. CSR does not have a significant effect on the company's financial performance because the public's response to CSR affects the company's financial performance because of public trust in a company. Whether the success of a company is of a high level is seen from how the community gives response to the company (Parengkuan, 2017). Another reason is that in implementing CSR, there are costs to incur. Accordingly, the company profits have decreased and resulted in a decrease in the ROA value. $A$ good CSR performance happens when more and more CSR activities are carried out and for investors this becomes less efficient (Fatah and Haryanto, 2016). CSR is a long-term investment activity. By implementing CSR indirectly, the company makes long-term investments. For instance, the development of human resources in the company's internal environment and the surrounding community will make employee's performance better. The maintenance of relationship between the company and the environment will also improve the company's image. By carrying out the CSR activities, the company can increase its public trust in their products. Therefore, the company's reputation stands out in the eyes of the community. The company can not enjoy the benefits of CSR instantly. The benefits of CSR are earned in a longterm. Nevertheless, this research is conducted in the annual report and sustainability report in the same year so that the results obtained will not show any influence.

This research is different from the research conducted by Husnan and Pamudji (2013), Putra (2015), Heryanto and Juliarto (2017), all of which state that CSR affects ROA.

\section{The Effect of the CSR Disclosure on the Value of the Company}

The second hypothesis is that CSR disclosure has an effect on the company value. From the result of statistical data processed through the significance test, it is 0.253 , which is greater than the $5 \%$ error level $(\alpha=0.05)$. This means that $\mathrm{H} 2$, which states that CSR disclosure affects the company value, is rejected. It can be summed up that CSR disclosure does not have a significant effect on the company value. This reflects that CSR disclosure is not a factor that determines the company value. CSR disclosure cannot be an indicator of priority for investors or stakeholders to invest in a company.

This research is in line with researches by Karundeng, et al (2017), Sari and Priantinah (2018), Fajriana and Priantinah (2016), all of which state that CSR has no significant effect on the company value. It is due to the absence of government regulation regarding CSR indicators to be disclosed. There are still a lot of companies which are the research samples which have not applied the GRI standards in disclosing the corporate CSR activities. The lack of quality of CSR disclosure and disregard of the standards issued by GRI are factors that cause CSR practices to have no effect on the company value. The lack of quality of CSR disclosure is caused by the company's motivation to carry out CSR not for social responsibility. Rather, it is for the company to comply with the laws set by the government and to avoid conflicts with the community and employees over the impact caused by the company's operational activities.

According to Purawan and Wirakusuma (2020), the cause of CSR being void of effects on company value is the lack of investor's attention to CSR disclosure by companies. The disclosure 
of CSR by the company is not in line with the prevailing conditions. Investors do not make CSR disclosure a criterion for investing. Rather, they pay attention to the company's financial performance. Despite the company disclosure of its CSR maximally, should the company experience a loss, the price of traded shares will decrease.

The results of this study are different from those of Fasya (2018), Dewi and Biyantari (2017), all of which state that CSR affects the company value.

\section{CONCLUSION AND SUGGESTION}

The conclusion of this study is the disclosure of CSR does not have a significant effect on profitability nor does it affect the company value. This is due to various factors, namely the public's response to CSR, CSR incurring costs so that investors may find it to be less efficient. The benefits of CSR are not obtained instantly. On the contrary, they are long term ones. There are also the lack of quality of CSR disclosure by companies and the lack of investor attention to CSR disclosure.

The suggestion for companies is to keep conducting CSR activities because it is a long-term investment activity. CSR is instructive to apply because its activities are forms of company's concern over the surrounding environment.

\section{REFERENCES}

Dewi, I Gusti Ayu Agung Omika dan Ni Komang Biyantari. Pengaruh Budaya Tri Hita Karana Pada Hubungan Corporate Social Responsibility Dan Nilai Perusahaan Pada Indonesia Tourism Development Corporation. Jurnal Ilmiah Akuntansi dan Bisnis, 2(2), 247-258.

Ekasari, Novita dan Yenny Christine (2012). Pengaruh Corporate Social
Responsibility Terhadap Profitabilitas PT. Telkom Tbk Sebagai Pemenang CSR Award 2008. AKRUAL: Jurnal Akuntansi, 3(2), 196-208.

Fahmi, Irham. (2014). Etika Bisnis: Teori, Kasus dan Solusi. Bandung: Alfabeta.

Fasya, Azalia (2018). Pengaruh Pengungkapan Corporate Social Responsibilty Terhadap Nilai Perusahaan Dengan Profitabilitas Sebagai Variabel Moderasi. Jurnal Informasi Perpajakan, Akuntansi dan Keuangan Publik (JIPAK), 13(2), 145162.

Fatah, Karina Adhitya dan Melinda Haryanto. (2016). Pengaruh Pengungkapan Corporate Social Responsibility Terhadap Profitabilitas Perusahaan: Studi Empiris Pada Perusahaan Manufaktur Sektor Industri Dasar dan Kimia yang Terdaftar di Bursa Efek Indonesia. Jurnal Ekonomi dan Bisnis - EKONOMIS, 10(2), 1-20.

Hadi, Nor. (2011). Corporate Social Responsibility. Yogyakarta: Graha IImu.

Husnan, Ahmad dan Sugeng Pamudji (2013). Pengaruh Corporate Social Responsibility (CSR Disclosure) Terhadap Kinerja Keuangan Perusahaan. Diponegoro Journal Of Accounting, 2(2), 1-8.

Hery. (2017). Kajian Riset Akuntansi. Jakarta: PT. Grasindo.

Hery. (2017). Teori Akuntansi (Pendekatan Konsep dan Analisis). Jakarta: PT. Grasindo.

Heryanto, Robby dan Agung Juliarto (2017). Pengaruh Corporate Social Responsibility Terhadap Profitabilitas Perusahaan (Studi Empiris Pada Perusahaan Manufaktur Yang Terdaftar Di Bursa Efek Indonesia Periode 2014- 
2015). Diponegoro Journal Of Rochayatun, Sulis. (2016). Faktor-faktor Accounting, 6(4), 1-8.

Yang Mempengaruhi Corporate Social Responsiblity (CSRD). Jurnal Penelitian IImu Ekonomi WIGA, 6(1), 63-79.

Herman Karamoy (2017). Analisis

Pengaruh Corporate Social

Responsibility Terhadap Nilai

Perusahaan Dengan Profitabilitas,

Kepemilikan Manajemen Dan Ukuran

Perusahaan Sebagai Variabel

Moderasi (Studi Empiris Pada

Perusahaan Pertambangan Yang

Terdaftar Di Bursa Efek Jakarta tahun 2012-2016). Jurnal Riset Akuntansi Dan Auditing "Goodwill", 8(2), 1-10.

Sari, Putri Yanindha dan Denies Priantinah (2018). Pengaruh Kinerja Keuangan Dan Corporate Social Responsibility (CSR) Terhadap Nilai Perusahaan Pada Bank Yang Terdaftar Di Bursa Efek Indonesia Periode 2011-2015. Jurnal Nominal: Barometer Riset Akuntansi dan Manajemen, VII(1), 111125.

Parengkuan, Winnie Eveline (2017). Pengaruh CSR Terhadap Kinerja Keuangan Perusahaan Manufaktur Yang Terdaftar di BEI. Jurnal EMBA: Jurnal Riset Ekonomi, Manajemen, Bisnis Dan Akuntansi, 5(2), 564-571.

Untung, Budi. (2012). Hukum dan Etika Bisnis. Yogyakarta: Andi.

https://www.bengkulunews.co.id. 2020/06/09. 100 perusahaan raih Indonesia Top CSR of the year 2020.

Purawan, Ngakan Made Dwi dan Made Gede Wirakusuma ( 2020). Pengaruh Pengungkapan Corporate Social Responsibility Pada Nilai Perusahaan Dengan Kinerja Lingkungan Sebagai Pemoderasi. E-Jurnal Akuntansi (E$J A), 30(2)$, 447-459.

Putra, Anggara Satria. (2015). Pengaruh Corporate Social Responsibility Terhadap Profitabilitas Perusahaan (Studi Empiris Pada Perusahaan Sektor Industri Barang Konsumsi Yang Terdaftar Di Bursa Efek Indonesia Tahun 2010-2013). Jurnal Nominal: Barometer Riset Akuntansi dan Manajemen, IV(2), 88-110.

Riyanto, Bambang. (2012). Dasar-dasar Pembelanjaan Perusahaan, Edisi 4. Yogyakarta: BPFE. 